DOI: https://doi.org/10.31933/dijms.v2i1

Received: 1 October 2020, Revised: 9 October 2020, Publish: 18 October 2020

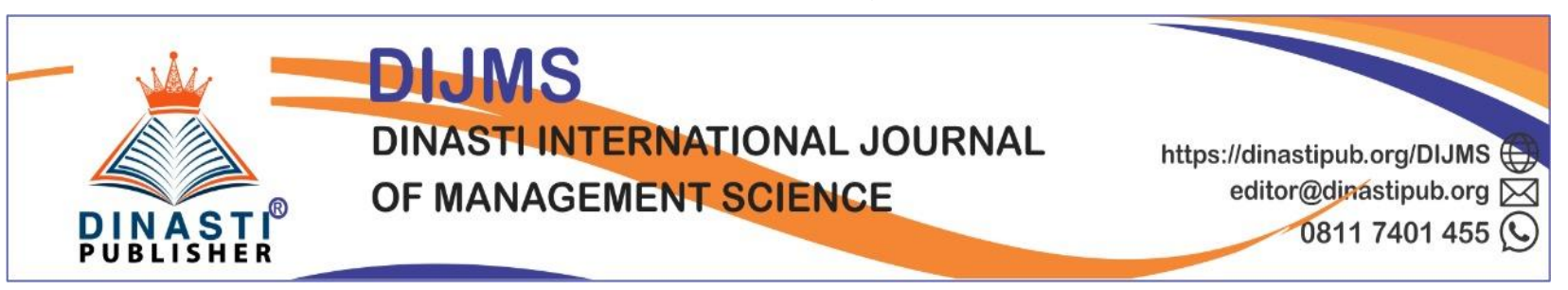

\title{
CUSTOMER EXPERIENCE OF MULTI-SERVICE PLATFORM: THE MEDIATING ROLE BETWEEN BRAND EXTENSION STRATEGY AND BRAND IMAGE
}

\author{
Daniel Hermawan ${ }^{1}$, Theresia Gunawan ${ }^{2}$, Zhiwen $\mathbf{L i}^{3}$ \\ 1) Parahyangan Catholic University, Bandung, Indonesia, daniel.hermawan@unpar.ac.id \\ 2) Parahyangan Catholic University, Bandung, Indonesia, theresia@unpar.ac.id \\ 3) Jiangsu University, Zhenjiang, The People's Republic of China, zhiwenli@mail.ujs.edu.cn
}

\section{Corresponding Author: Daniel Hermawan ${ }^{1}$}

\begin{abstract}
As the pioneer in multi-service platform, GO-JEK faces tight competition from other similar type of businesses. GO-JEK extends its product through a lot of extensions to strengthen GOJEK's position. This research aims to analyze the impact of brand extension strategy on brand image with customer experience as the mediating role. The type of research is explanative, research method using survey with quantitative approach, and data analyze using Sobel test to determine the impact of brand extension strategy on brand image with customer experience as the mediating role. Based on data analyze result from 378 samples, brand extension strategy gives significant contribution to customer experience, customer experience gives significant contribution to brand image, brand extension strategy gives significant contribution to brand image, and brand extension strategy through customer experience give significant contribution to brand image. So there's mediating role of customer experience to mediating the impact of brand extension strategy on brand image of GO-JEK in Bandung.
\end{abstract}

Keywords: brand extension strategy, customer experience, brand image

\section{INTRODUCTION}

Internet plays an important role in the business world. Internet penetrated into business process to give value added to customer. One of the internet existences in business process is mobile application. Through mobile applications, customers can order and buy something using internet, either products or services. Easy, fast, and reliable are some characteristics of mobile applications.

In Indonesia, there are quite a lot of multi-service platform. They are GO-JEK, GrabBike, UBER, and many more. Each company tries to show its competitive advantage to attract customer. As the pioneer in multi-service platform, GO-JEK faces tight competition from other similar type of businesses. GO-JEK tries to manage its position as a market leader through some innovation strategy aimed at maintaining customer loyalty. 
GO-JEK extends its product through a lot of extensions. From the core product GO-RIDE as motorcycle transportation service, GO-JEK now extends into GO-CAR, GO-FOOD, GO-BILLS, GO-MART, GO-SEND, GO-BOX, GO-PULSA, GO-MASSAGE, GO-CLEAN, GO-GLAM, GOTIX, GO-AUTO, GO-FIX, GO-LAUNDRY, GO-MED, GO-BUSWAY, GO-BLUEBIRD, and GOSHOP. This GO-JEK's brand extension strategy does to strengthen GO-JEK's position in Indonesia market.

Brand is an identity attached to a product or service, either in the form of a logo, color, or the attributes attached to the product (Broniarczyk \& Alba, 2004). Managing strong brand is very important for company to reduce their marketing cost. At the same time, strong brand also make customer easy to remember and repeat purchases in the future. A strong brand gives trust to people to choose a new product or service that is issued. In addition, it reduces the company's risk of introducing new products under different brands. Therefore, companies use brand extension strategy considering this factor (Martinez \& Pina, 2003).

Brand extension strategy is a new style for brand management, which creates the value for a single name and makes it a mega brand (Kapferer, 2001). The brand extension strategy is used to gain a wider market share with different business sectors (Iversen \& Hem, 2011).

The existence of a parent brand in the brand extension strategy will make it easier for brands to communicate the new products or services offered with the positioning given by the parent brand (Fedorikhin, 2008). It costs a lot to build a new brand, so that the brand extension strategy is used by several companies to enter new markets (Chun, 2015). The brand extension strategy is used because the well-known parent brand name will reduce market risk, particularly in consumer acceptance of the new product or service (Milewicz \& Herbig, 2004).

The success of the brand extension strategy is largely determined by the suitability of the parent brand's image with the brand extension being developed. If the product or service being developed has the same value as an existing brand, the success rate of the brand extension can be said to be quite high. Conversely, when the brand extension being developed is far different from the parent brand, the risk of failure will be higher (Sheinin \& Schmitt, 2004).

The result of brand extension strategy usage, either its successful or failed can be seen from correlation and attachment between brand extension strategies with parent brand (Pina, Martinez, Chernatony, \& Drury, 2006). A successful brand extension strategy story can be seen from Unilever company, which produces a lot of different brands alongside its parent brand. Brand extension makes Unilever brand stronger and reputable in providing customers' daily needs. Failure brand extension strategy can be seen from Harley-Davidson. Harley-Davidson extended its product into perfume. The problem was that customers did not associate this brand with a good smell. Instead, customers think of the smell of motor oil and sweat. Harley-Davidson learnt from this mistake and is now focusing on its areas of expertise.

Customer experience is the result of interactions between consumers and companies (Ding, $\mathrm{Hu}$, Verma, \& Wardell, 2010). Customer experience is obtained from interactions with staff, the atmosphere obtained, the services provided, and the strength of the brand in building deep relationships with consumers. (Xu \& Chan, 2010).

Customer experience plays an important role in increasing customer satisfaction, customer loyalty, competitive advantage, sales revenue, and customer relationships (Client Heartbeat, 2014). 
A good consumer experience can build a good partnership ecosystem with customers, as well as build a good customer base for the company (KPMG LLP, 2011).

Brand image is the perception in the mind of the customer regarding the brand (Keller, 2008). When a name or attribute is mentioned, the brand image will appear in the mind of the customer, both in the form of brand characteristics and the types of products and services that the brand issues.

A good brand image that is embedded in the minds of customers will provide benefits for the company because customers have an emotional closeness in choosing the brand. A strong brand image makes customers tend to choose products or services that are well known (Mohammadian \& Ronaghi, 2010).

A good brand extension strategy can strengthen the parent brand (Chen \& Liu, 2004). Creating a new brand carries a greater risk and investment than creating a brand extension, as such GO-JEK uses brand extension strategy to enter new markets. In this study, research will focus on the impact of brand extension strategy on GO-JEK brand image through customer experience as mediating variable. Also, research will find out the significance of brand extension strategy on GOJEK's business progress.

\section{LITERATURE REVIEW}

\section{Brand}

A brand is a name with power to influence buyers. A name used as a brand must have a strength that defines uniqueness, quality, and builds confidence in the quality of the product or service produced (Keller, 2008). In building a customer base, a brand must have a strong identity in communicating the advantages of the product or service it has, the positioning chosen, and its interactivity with customers.

Brands provide deep meaning to customers. A brand provides an identity as a responsible or not responsible producer, manufacturer or distributor of products or services. Brands also have special meanings that are tested over time through the quality, uniqueness, and identity developed. Through the brand name, customers can easily identify the product or service they want to consume (Kotler \& Armstrong, 2002). Most of purchasing decisions occur because customers understand the brands and attributes they use in introducing products or services.

From an economic perspective, brands make it easy for customers to reduce costs for finding products or services. Understanding the brand provides an overview for customers about quality expectations, characteristics, and other attributes (Keller, 2008).

\section{Brand Extension Strategy}

A brand extension strategy is a strategy that brands that are already successful in the market can use to introduce new products or services. Kotler and Armstrong (2002) mention that brand extension strategy is used to introduce new products or services in a different business sector from the parent brand.

Brand extension strategy can reduce the risk of failure and increase market acceptance of a new product or service (Pina, Martinez, Chernatony, \& Drury, 2006). Brand extension strategy is an alternative marketing choice method for large companies compared to developing a new brand which is expensive. 
Brand extension strategy will make it easier for the market to recognize new products or services because it has links with parent brands that have been around for a long time and are known by the public first. The closeness of customers to the parent brand makes customers feel familiar and it is not impossible if the parent brand market segment will be interested in trying the brand extensions offered by the parent brand (Milewicz \& Herbig, 2004).

Brand extension strategy comes in two primary forms: horizontal and vertical. Horizontally, brand extension is applied to a business sector that is completely different from the parent brand (Sheinin \& Schmitt, 2004). Vertically, brand extensions are introduced in the same product or service line, it's just that they are displayed with different quality and prices, either more expensive or cheaper (Keller \& Aaker, 2002).

\section{Customer Experience}

Customer experience involves both cognitive and emotional aspects in the buying process (Klaus P., 2013). Customer experience is the interaction that exists between companies, either directly or indirectly. Directly, the customer experience is obtained when customers interact with staff, get service, and carry out the buying process. Indirectly, customer experience is obtained through company identity, whether advertisements, websites, social media, or other attributes that describe the company (Meyer C., 2007).

Customer experience can be different based on the typical of customers in the market. Customers can be divided into several categories based on age and characteristics, such as Generation X, Generation Y, Generation Z, and Generation Alpha (Sterbenz, 2014). Generation X is born between 1961 - 1980, which is generation that has "work-life balance" life and love to use personal computer. Generation X communication method is using e-mail and text message (SMS) and face-to-face interaction. Generation Y is born between 1981 - 1994, which is generation that have "freedom and flexibility" life and love to use tablet or smartphones. Generation Y communication method is using text or social media and face-to-face interaction (The Sydney Morning Herald, 2010).

Generation Z is born between 1995 - 2009, which is generation that have "security and stability" life and love to use smartphones. Generation $\mathrm{Z}$ communication method is using smartphones and love digitally crowd-sourced to finding solution. Generation Alpha is born after 2010, which is generation that have "transformative and technology" life and can't life without gadget. Generation Alpha is involved with technology products and spends the most of time in social media dan online games (CROWD.DNA, 2015).

Customer experience is considered as a psychological concept, which is a comprehensive, subjective response developed from customer contact with companies. This contact could include different levels of customer participation (Lemke \& Hugh, 2011).

\section{Brand Image}

Brand image is consisted of customers' opinion, attitude, and emotion toward a brand, which reflects the cognitive or psychological elements of the brand (Fedorikhin, 2008). A brand image is how the customers perceive the brand (Faircloth, Capella, \& Alford, 2001). Brand image is a set of associations which might not even reflect the objective reality. 
Brand image is an attraction that allows customers to bond with the brand, both logically and emotionally. Brand image forms associations in the minds of customers that make brands easy to remember, recognize, and more likely choose (Lassar, Mittal, \& Sharma, 2005).

\section{Relation between Brand Extension Strategy, Customer Experience, and Brand Image}

The power of customer association in defining a product or service for a brand will greatly affect the identity of the brand. If brand image is positive, it will strengthen the identity of the brand that is built (Aaker, 2002), otherwise when these identities are not strong enough, there can be a dilution of brands that provide an identity that is different from the company's design (Bhat \& Reddy, 2001).

Brand extension strategy is a suitable strategy to use when its existence can strengthen the brand equity of the parent brand (Aaker, 2002) and improving brand positioning (Kim, Lavack, \& Smith, 2001). It cannot be denied that brand extensions can cause confusion for customers when they are displayed without a mature identity or different from the parent brand (Bhat \& Reddy, 2001).

Author proposed the usage of brand extension strategy through customer experience will strengthen the impact between brand extension strategy and brand image. Customer experience becomes the mediating variable that gives confidence to customer to give judgment for brand image of the product as the whole, either it positive or negative.

The brand image of the company will be influenced by the brand extension used. According to Czellar (2003), knowledge of brand extensions is very much influenced by the brand image of the parent brand. The match between identity, expertise, and product or service linkages will be the key to the success of the brand extension strategy in strengthening the brand image (Salinas, 2009).

\section{RESEARCH METHODS}

Research is use explanative research. Explanative research tries to explain causal relation about one social phenomenon (Neuman, 2003). Author wants to see the impact between brand extension strategy on GO-JEK's brand image through customer experience as mediating variable. Research method that used in this research is survey with quantitative approach. Survey method chooses because author wants to analyze characteristic or cause effect relations between variables without any author interventions. Author wants to know the relation between brand extension strategies on GO-JEK's brand image through customer experience exactly as fact in the field (Sugiyono, 2014).

Meanwhile not available secondary data that describes exactly the number of GO-JEK's user in Bandung, cause no sampling framework. Based on this reason, author select non-probability sampling collection method since in this technique, sampling framework not necessary (Eriyanto, 2007). Non-probability technique method also not gives the same chance for every population member to be chosen as sample member (Sugiyono, 2014).

Non-probability sampling that will be used is purposive sampling technique. Purposive sampling is used when the researcher selects respondents who are considered relevant, competent, and in accordance with the indicators measured in the study.

Respondent for this questionnaire is GO-JEK's customer, which already experienced GOJEK's brand extension product through GO-JEK's mobile application (Eriyanto, 2007). This 
technique chosen since author want get the real information about customer's respond about brand extension strategy that done by GO-JEK.

The minimum number of sample that will be observed is 270 respondents with trust interval $95 \%$, heterogenic population variants, and margin error $\pm 6 \%$. These numbers choose to analyze holistic customer perception about GO-JEK's brand extension strategy on GO-JEK's brand image through customer experience and get accurate data during doing research.

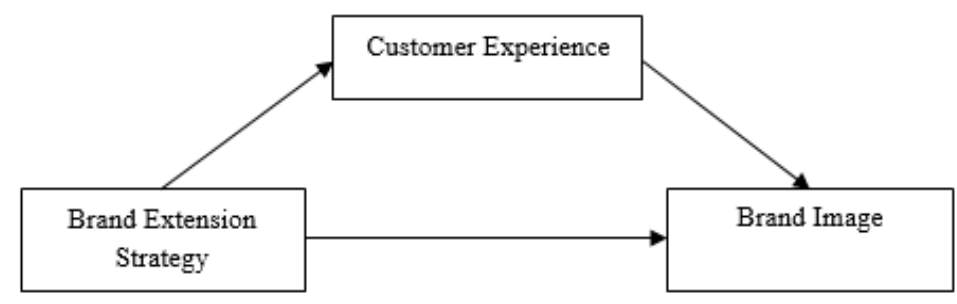

Figure 1. Research Model

It has been studied that brand extensions are able to reduce risks in introducing new products, reduce promotional costs, and increase consumer acceptance of new products (Kushwaha, 2012). Customers are more savvy and they make decisions based on the credibility and the past experience with the brand (Thanwarani, Virani, \& Thanwarani, 2014). Brand assets are built by the company based on fulfilling customer needs and desires which are translated into advertisements and services provided to give customers confidence in the buying process. Brands provide a good customer experience to build a good brand image in the eyes of customers (Ambler, et al., 2002).

Brand extensions will be successful when they are able to provide expectations of the same benefits that will be obtained from the parent brand (Ogbuji, Kalu, Maduenyoghasi, \& Samson, 2014). Quality compliance will give the brand extension success along with the brand image of the parent brand (Ahmad, Mujeeb, \& Rajput, 2011). Brand image is the final form of accumulated interactions, experiences, communications, and perceptions that customers get from touch points with the company (Abdavi \& Shiralizadeh, 2015). Customers who find products or services that are already known to provide good quality, then have the same perception of the brand extension issued by the parent brand. It is important for brands to ensure that the customer experience can match or exceed the expectations that customers have (Aidin \& Akbar, 2013).

Hla: Brand extension strategy is having positive impact and significant on customer experience of GO-JEK in Bandung

H1b: Customer experience is having positive impact and significant on brand image of GO-JEK in Bandung

H1c: Brand extension strategy is having positive impact and significant on brand image of GO-JEK in Bandung

HId: Brand extension strategy is having positive impact and significant on brand image of GO-JEK through customer experience in Bandung

FINDINGS AND DISCUSSION 
Respondent data is all respondent identity that regarded relevant with identified problem. Here shown respondent data based on sex, age, profession, domicile, location of reservation, hours of use, frequency of use, income level per month, spending level for GO-JEK service per month, and overall spending level per month.

Table 1. Profile of the Respondent

\begin{tabular}{lcc}
\hline \multicolumn{1}{c}{ Profile } & Majority & $\%$ \\
\hline Sex & Female & 57,1 \\
Age & $19-25$ years old & 50 \\
Profession & Employee & 58,2 \\
Domicile & South Bandung & 35 \\
Location of Reservation & Home & 73,3 \\
Hours of Use & $18.00-20.00 \mathrm{pm}$ & 30,4 \\
Frequency of Use & More than 2 weeks once & 26 \\
Income Level per Month & 2.500.000 - 3.000.000 IDR & 16,1 \\
Spending Level for GO-JEK Service per & $<50.000$ IDR & 32,5 \\
Month & & \\
Overall Spending Level per Month & <00.000 IDR & 21,4 \\
The Most Used GO-JEK Products & GO-RIDE & 63,5 \\
& GO-FOOD & 56,9 \\
& GO-CAR & 45 \\
The Less Used GO-JEK Products & GO-AUTO & 0,5 \\
& GO-GLAM & 0,8 \\
& GO-MED & 1
\end{tabular}

Coefficient determination (r2) used to measure how far independent variable ability in give contribution or impact to dependent variable.

Table 2. Coefficient Determination

\begin{tabular}{cc}
\hline Coefficient Determination & R Square \\
\hline Brand Extension Strategy on Customer Experience & 0,570 \\
Customer Experience on Brand Image & 0,520 \\
Brand Extension Strategy on Brand Image & 0,662
\end{tabular}

Table 3. Hypothesis Test

\begin{tabular}{cccc}
\hline Hypothesis Test & t count & t table & Results \\
\hline Brand Extension Strategy on Customer Experience & 22,323 & 1,980 & $\mathrm{H}_{1 \mathrm{a}}$ accepted \\
Customer Experience on Brand Image & 20,167 & 1,980 & $\mathrm{H}_{1 \mathrm{~b}}$ accepted \\
Brand Extension Strategy on Brand Image & 27,147 & 1,980 & $\mathrm{H}_{1 \mathrm{c}}$ accepted
\end{tabular}

Based on output Sobel test, significance test with Sobel test need big amount of sample, at small sample cases there's trend not normally distributed, so significance test result can be misled. As alternative, bootstrapping technique can be done to do test with resampling until 1000 times. Bootstrapping result gives estimation indirect effect Brand Extension Strategy to Brand Image through Customer Experience, standard error and confidence level value 95\%. Can be seen that bootstrapping standard error is more than normal distribution assumption, that's 0,0367 compare with 0,0314 , so that $t$ value from indirect effect using bootstrapping is becoming: 


$$
t=\frac{0,1717}{0,0367}=4,678
$$

In this case, $t$ counting is $4,678>\mathrm{t}$ table value is $1,96(\alpha=0,05)$, so can be conclude that there's significant mediation influence. The type of mediation is partial mediation, since the relation between brand extension strategy as independent variable on brand image as dependent variable significant, while mediation variable also significant.

Indirect effects can be quantified easily using Ordinary Least Square (OLS) regression and some simple rules of path analysis. $\mathrm{X}$ can also affect $\mathrm{Y}$ directly, meaning independent of its effect on M (Hayes, 2013).

The impact of mediating variable tested using path analysis method. Path analysis is expansion from multiple linear regression analysis or path analysis is regression analysis usage to predict causality relation between variable that already decided before based on theory. Path analysis can't decide relation causal and effect and also can't be used as substitution for researcher to see causality relation between variables. Path analysis will determine relation pattern between three or more variable and can't be use to confirm or reject hypothesis imaginary causality.

Path diagram give explicitly causal relation between variables based on the theory. Arrow shows relation between variables. Model moves from left to right with priority implication causal relation variable those close to left. Every p value describes path and path coefficient.

Base on Figure 2., submitted relation based on theory that X (Brand Extension Strategy) has direct relation with Brand Image (Y) (p1). X (Brand Extension Strategy) also have indirect effect to Y (Brand Image), that're from X (Brand Extension Strategy to M (Customer Experience) and then on Y (Brand Image).

Total effect relation from X on Y (correlation between Brand Extension Strategy and Brand Image) same with direct effect Brand Extension Strategy on Brand Image (path coefficient or regression $\mathrm{p}$ ) plus indirect effect, that's path coefficient from $\mathrm{X}$ to $\mathrm{M}$ (p2) multiple path coefficient from $\mathrm{M}$ to $\mathrm{Y}(\mathrm{p} 3)$.

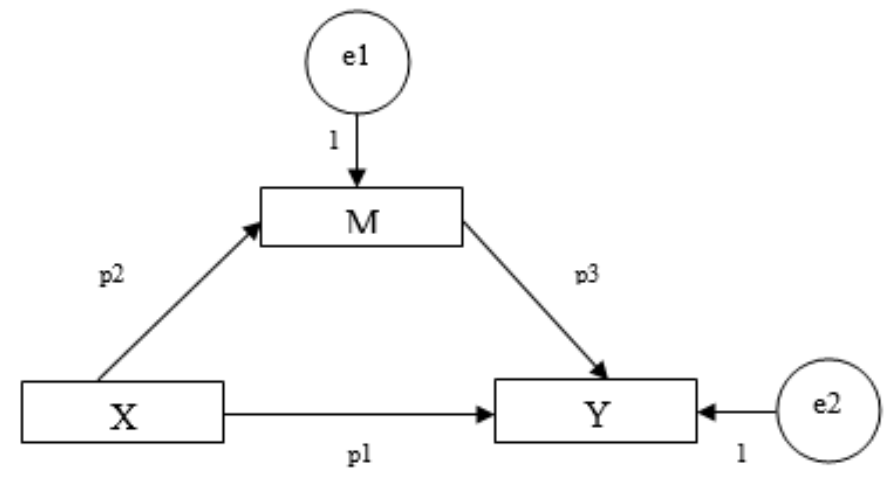

Figure 2. Path Analysis Diagram

Direct effect Brand Extension Strategy $(X)$ to Brand Image $(Y)=p 1$

Indirect effect Brand Extension Strategy $(\mathrm{X})$ to Customer Experience $(\mathrm{M})$ to Brand Image $(\mathrm{Y})=\mathrm{p} 2$ x p3

Total effect (correlation Brand Extension Strategy to Brand Image $)=p 1+(p 2 \times p 3)$ 
Direct relation happens if there's one variable impacting the other variable without third variable that mediating relation between that two variables. Indirect relation happens if there's third variable that mediating these two variables. Every dependent variable will have arrow that go to e and e have function to describe total unexplained variance from variable e.

Table 4. SPSS Results for Path Analysis Effect

\begin{tabular}{ccc}
\hline Effect & Unstandardized Coefficients B & Sig. \\
\hline p1 & 0,575 & 0,000 \\
p2 & 0,629 & 0,000 \\
p3 & 0,273 & 0,000
\end{tabular}

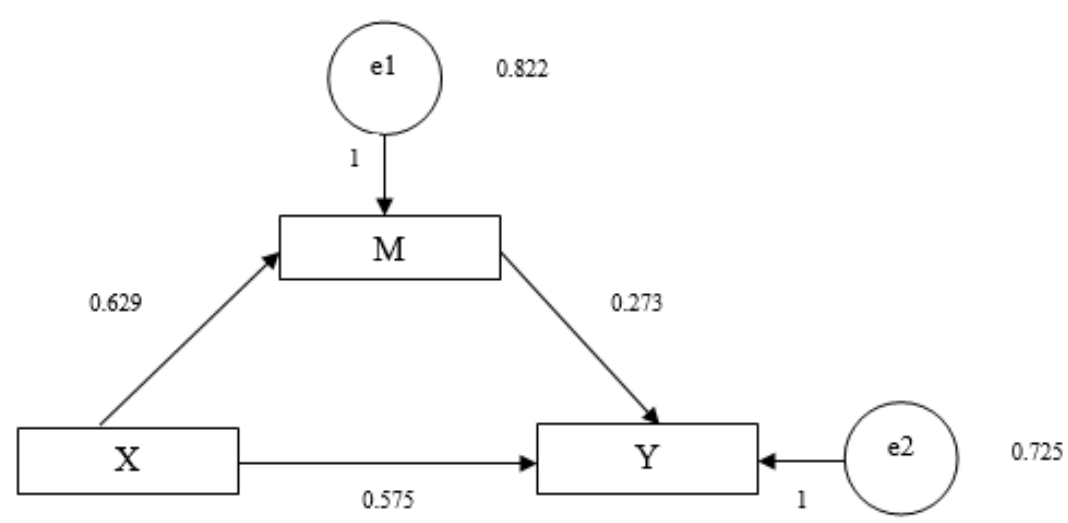

Figure 3. Path Diagram Analysis

The result of path analysis in Figure 3. shows that Brand Extension Strategy can directly effect on Brand Image and also can be indirect effect from Brand Extension Strategy on Customer Experience (as mediating) and then on Brand Image. The amount of direct effect is 0,629, meanwhile indirect effect must be count with multiple indirect coefficient, that're $(0,629) \times(0,273)=0,172$ or total impact Brand Extension Strategy on Brand Image $=0,575+((0,629) \times(0,273))=0,747$.

Table 5. Direct, Indirect, and Total Effect

\begin{tabular}{cc}
\hline Direct Effect & \\
\hline Brand Extension Strategy $\rightarrow$ Customer Experience $(\mathrm{X} \rightarrow \mathrm{M})$ & 0,6292 \\
Customer Experience $\rightarrow$ Brand Image $(\mathrm{M} \rightarrow \mathrm{Y})$ & 0,2728 \\
Brand Extension Strategy $\rightarrow$ Brand Image $(\mathrm{X} \rightarrow \mathrm{Y})$ & 0,5754 \\
\hline Indirect effect & \\
\hline Brand Extension Strategy $\rightarrow$ Customer Experience $\rightarrow$ Brand Image $(\mathrm{X} \rightarrow \mathrm{M} \rightarrow \mathrm{Y})$ & 0,1717 \\
\hline Total effect & 0,7471
\end{tabular}

From this results, also can be conclude that Customer Experience as mediating variable has contribution to the impact of brand extension strategy on brand image. That's means that the impact 
of brand extension strategy getting stronger after customer experience act as mediating variable on brand image, that is 0,1717 .

Even relatively small, but this result also show that brand extension strategy will not work well without a good customer experience, since one bad customer experience will decrease GO-JEK's brand image in customer perception. Brand Image (Y) will be impacted stronger with the mediating role of customer experience with 0,7471 together with Brand Extension Strategy (X). Also, customer experience was proved as a mediator of the effect of brand extension strategy on GO-JEK's brand image.

\section{CONCLUSION AND RECOMMENDATION}

Based on research conducted, GO-JEK is able to provide convenience and practicality in the daily lives of its customers. The number of brand extension strategies undertaken by GO-JEK in various business sectors in the GO-JEK application is a solution for people in Bandung to carry out various activities quickly and easily.

Brand extension strategy will successfully influence the customer experience when the parent brand that produces co-brands is able to produce good past experiences, both in terms of products, prices, and services provided so that customers are interested in trying the co-brands produced by the parent brand.

A good customer experience will certainly produce a good brand image in the eyes of customers. Customers will judge the merits of the brand image of the customer experience gained from the first time using the product or service offered. Customer experience will establish the credibility of a business for the company's brand image. The role of customer experience in strengthen brand image also supported by Venkat (2007) along with customer satisfaction and brand loyalty.

Brand extension strategy will have a significant influence on brand image when supported by a match between the product or service offered by the parent brand and the product or service issued by the co-brand. Brand extension strategy will strengthen the brand image of the parent brand when producing products or services that meet customer expectations. This study contrasts with the research conducted Poerwadi (2019) that mentions brand extension strategy affects brand trust, but does not affect brand image and brand equity.

Brand extension strategy supported by good customer experience will produce a good brand image for GO-JEK. New co-brands produced under the GO-JEK parent brand will be evaluated positively according to past experiences experienced by customers when using products or services issued by GO-JEK. This result supported by Hussain (2016) that mentions parent brand experience is one of critical factor that support brand extension strategy success.

This research is conducted in the city of Bandung, so it possible to make an overview of the influence of GO-JEK's brand extension strategies on brand image with customer experience as a mediating variable in other cities and Indonesia in general considering the different customer's characteristics and culture. The other variables that might influence this research, such as price, promotion, service quality, etc. can be developed as further research from this research. Also, it's possible to learn customer behavior and customer's touch point to analyze GO-JEK's customer experience in terms of buying decision in brand extension strategy. 


\section{BIBLIOGRAPHY}

Aaker, D. A. (2002). Brand Portfolio Strategy. New York: The Free Press.

Abdavi, F., \& Shiralizadeh, Z. (2015). The Effect of Brand Extension Strategy on Its Image: The Case of Majid Brand. Annals of Applied Sport Science, 39-48.

Ahmad, M. S., Mujeeb, E. u., \& Rajput, A. (2011). Does Brand Extension Impact Parent Brand: A Case of Johnson, UK. The Management \& Marketing Journal, 53-66. Universitaria Craiova: https://www.mnmk.ro > 5_Pakistan2 FFF

Aidin, T. N., \& Akbar, M. (2013). The Impact of Brand Extension on New Product from Customers' Perspective. International Research Journal of Applied and Basic Sciences, 789-800.

Ambler, T., Bhattacharya, C. B., Edell, J., Keller, K. L., Lemon, K. N., \& Mittal, V. (2002). Relating Brand and Customer Perspectives on Marketing Management. Journal of Service Research, 13-25.

Bhat, S., \& Reddy, S. K. (2001). The Impact of Parent Brand Attribute Associations and Effect on Brand Extension Evaluation. Journal of Business Research, 111-122.

Biedenbach, G., \& Marell, A. (2010). The Impact of Customer Experience on Brand Equity in a B2B Services Setting. Journal of Brand Management, 446-458.

Broniarczyk, S. M., \& Alba, J. W. (2004). The Importance of the Brand in Brand Extension. Journal of Marketing Research, 214-218.

Chen, K., \& Liu, C. M. (2004). Positive Brand Extension Trial and Choice of Parent Brand. Journal of Product and Brand Management, 25-36.

Chun, H. H. (2015). Strategic Benefits of Low Fit Brand Extensions: When and Why? Journal of Consumer Psychology, 577-595.

Client Heartbeat. (2014, June 17). Retrieved March 14, 2017, from Why Customer Experience is Important: 7 Reasons: http://blog.clientheartbeat.com/why-customer-experience-is-important/

CROWD.DNA. (2015, April 21). Retrieved April 27, 2017, from Generation Alpha: http://www.crowddna.com/2015/04/generation-alpha/

Czellar, S. (2003). Consumer Attitude Towards Brand Extensions: An Integrative Model and Research Propositions. International Journal Research of Marketing, 97-115.

Ding, D. X., Hu, P. J., Verma, R., \& Wardell, D. G. (2010). The impact of service system design and flow experience on customer satisfaction in online financial services. Journal of Service Research, 96-110.

Eriyanto. (2007). Teknik Sampling Analisis Opini Publik. Yogyakarta: PT. LKIS Pelangi Aksara.

Faircloth, J. B., Capella, L. M., \& Alford, B. L. (2001). The Effect of Brand Attitude and Brand Image on Brand Equity. Journal of Marketing Theory and Practice, 61-75.

Fedorikhin, A. (2008). Beyond Fit and Attitude: The Effect of Emotional Attachment on Consumer Responses to Brand Extensions. Journal of Consumer Psychology, 281-291.

Hayes, A. F. (2013). Introduction to Mediation, Moderation, and Conditional Process Analysis (A Regression-Based Approach). New York: The Guilford Press.

Hussain, S., \& Rashid, Y. (2016). Brand Extension Success Elements: A Conceptual Framework. Journal of Business Administration and Education Volume 8, Number 1, 23-35.

Iversen, N. M., \& Hem, L. E. (2011). Reciprocal Transfer Effects for Brand Extensions of Global or Local Origin: Evidence from Norway. International Marketing Review, 365-411.

Kapferer, J. N. (2001). Reinventing the Brand. London: Kogan Page Limited.

Keller, K. L. (2008). Strategic Brand Management: Building, Measuring, and Managing Brand Equity. New Jersey: Prentice-Hall. 
Keller, K. L., \& Aaker, D. A. (2002). The Effects of Sequential Introduction of Brand Extensions. Journal of Marketing Research, 35-50.

Kim, C. K., Lavack, A. M., \& Smith, M. (2001). Consumer Evaluation of Vertical Brand Extensions and Core Brands. Journal of Business Research, 211-222.

Klaus P., M. S. (2013). Towards a Better Measure of Customer Experience. International Journal of Market Research, 227-246.

Kotler, P., \& Armstrong, G. (2002). Principles of Marketing 9th Edition. Delhi: Pearson Education Asia.

KPMG LLP. (2011). Seven steps to better customer experience management. Amstelveen: KPMG International.

Kushwaha, T. (2012). Brand Extension: A Strategy for Competitive Advantage. SIBM, 18-27.

Lassar, W., Mittal, B., \& Sharma, A. (2005). Measuring Customer-Based Brand Equity. Journal of Consumer Marketing, 11-19.

Lemke, F. M., \& Hugh, W. (2011). Customer Experience Quality: An Exploration in Business and Consumer Contexts using Repertory Grid Technique. Journal of the Academy of Marketing Science, 846-869.

Martinez, E., \& Pina, J. (2003). The Negative Impact of Brand Extension on Parent Brand Image. Journal of Product \& Brand Management, 432-448.

Meyer C., S. A. (2007). Understanding customer experience. Harvard Business Review, 117-126.

Milewicz, J., \& Herbig, P. (2004). Evaluating The Brand Extension Decision Using a Model of Reputation Building. Journal of Product and Brand Management, 39-47.

Mohammadian, M., \& Ronaghi, M. H. (2010). Brand Promotion Strategies and Techniques. Tehran: Ketabe Mehraban Press.

Neuman, W. L. (2003). Social Research Methods: Qualitative and Quantitative Approaches, 5th Edition. Boston: Allyn and Bacon.

Ogbuji, C. N., Kalu, S. E., Maduenyoghasi, \& Samson, O. (2014). The Influence of Brand Extension Strategy on Marketing Performance of Soft Drinks Bottling Firms in Nigeria. American International Journal of Contemporary Research, 266-276.

Pina, J. M., Martinez, E., Chernatony, L., \& Drury, S. (2006). The Effect of Service Brand Extensions on Corporate Image an Empirical Model. European Journal of Marketing, 174-197.

Poerwadi, S., Suyanto, M., Hidayat, A., Purwadi, \& Eq, Z. M. (2019). Influence of Brand Extention Strategy, Brand Image and Brand Trust on Coffee Product's Brand Equity. International Journal of Marketing Studies Vol. 11, No. 3, 26-35.

Salinas, E. M. (2009). Modeling The Brand Extensions' Influence on Brand Image. Journal of Business Research, 50-60.

Sheinin, D. A., \& Schmitt, B. H. (2004). Extending Brands with New Product Concepts: The Role of Category Attribute Congruity, Brand Effect, and Brand Breadth. Journal of Business Research, 110.

Sterbenz, C. (2014, July 25). Business Insider. Retrieved April 27, 2017, from Here's Everything You Need To Know About 'Generation Alpha' — The Age Group Beyond Gen Z: http://www.businessinsider.co.id/generation-alpha-2014-

7/?r=US\&IR=T\#VtrLLpKBPxYUoX4C.97

Sugiyono. (2014). Metode Penelitian Administrasi. Bandung: Alfabeta.

Thanwarani, A., Virani, A., \& Thanwarani, M. (2014). Customers' Evaluation of Brand Extension: An Empirical Study of Skin Care Products. International Conference on Marketing (hal. 1-16). Institute of Business Administration Karachi. 
The Sydney Morning Herald. (2010, July 20). Retrieved April 27, 2017, from Talkin' 'bout my label: http://www.smh.com.au/lifestyle/diet-and-fitness/talkin-bout-my-label-20110720-1ho7s.html

Venkat, R. (2007). Impact of Customer Experience on Satisfaction, Brand Image and Loyalty: A Study in a Business-to-Business Context. ResearchGate.

Xu, J. B., \& Chan, A. (2010). A conceptual framework of hotel experience and customer-based brand equity: Some research questions and implications. International Journal of Contemporary Hospitality Management, 174-193 